\title{
KINETICS OF POTASSIUM DESORPTION FROM ENTISOL, VERTISOL AND MOLLISOL USING MISCIBLE DISPLACEMENT TECHNIQUE IN SULAMANI GOVERNORATE.
}

Ghafoor A. Mam Rasul

Univ. of Sulaimani / College of Agric.

Agric.
Mohamad A. J. Al-Obaidi

Univ. of Mosul / College of

Soil and Water Sci. Dept.

Soil and Water Sci. Dept.

\begin{abstract}
Kinetics of desorption were conducted on soil samples previously examined for adsorption characteristics from the surface horizon of seven soils of Sulaimani governorate in Kurdistan region of Iraq by using miscible displacement technique. The soil samples were leached with $0.001 M \mathrm{CaCl}_{2}$. The solution of $\mathrm{CaCl}_{2}$ was passed through the soil at flow velocities of $1 \mathrm{ml}$ min-1. Ten- milliliter aliquots were collected until $\mathrm{K}$ was not detected in the leachate.

Potassium desorption conformed to Elovich and Parabolic diffusion equations kinetics. Potassium desorption as plotted by Elovich and parabolic diffusion equations in Ca- saturated soils was rapid at first and leveled off with the time indicating more difficult desorption reaction. Apparent desorption rate coefficient $\left(\mathrm{K}_{\mathrm{d}}\right)$ for Elovich equation ranged from 0.0604 to $0.0441 \mathrm{cmol} \mathrm{kg}^{-1}$ $\min ^{-1}$, while the rate coefficient $\mathrm{K}$ desorption $\left(\mathrm{K}_{\mathrm{d}}\right)$ according to parabolic diffusion equation ranged from 0.0188 to $0.0476 \mathrm{cmol} \mathrm{kg}^{-1} \mathrm{~min}^{-1 / 2}$.
\end{abstract}

\section{INTRODUCTION}

Equilibrium reactions existing between solution and exchange phases of soil $\mathrm{K}$ profoundly influence $\mathrm{K}$ chemistry. The rate and direction of these reactions determine whether applied $\mathrm{K}$ well be leached into lower soil horizons, adsorbed by plants, converted into unavailable forms or released into available forms. Knowledge of the reaction rates between solution and exchangeable phases of soil $\mathrm{K}$ is necessary in order to predict the rate of added $\mathrm{K}$ fertilizer in soils and to properly make $\mathrm{K}$ fertilizer recommendation (Sparkes et al., 1980). Numerous experiments have been done on the potassium exchange equilibria with different cation systems on different soils, but information is inadequate on the kinetics of $\mathrm{K}$ desorption on complex soil system (Sparkes et al., 1980; Choudhary and Prasad, 1997). The kinetics of $\mathrm{K}$ desorption in heterogeneous soil systems was shown to conform to first order kinetics and to the parabolic diffusion law (Sivasubramanim and Talibudeen, 1972). Elovich equation was superior to the first order rate approach, since the former method tended to combine simultaneous first order reactions into one linear slop. Jardine and Sparks (1984) reported a rapid kinetics of exchange on external planar sites, slow kinetics of exchange on interlattice exchange sites and intermediate kinetics of exchange on interlattice edge sites. Sparks et al. (1980) investigated the kinetics of $\mathrm{K}$ exchange on soils and clay minerals. These studies have shown that the rate of exchange between solution and exchangeable $\mathrm{K}$ forms is 
diffusion controlled. Talibudeen et al. (1978) observed that the rate of release of soil $\mathrm{K}$ was linearly proportional to the square root of time whereas Mortland (1958) found that the release rate of $\mathrm{K}$ from biotite was of the Received 3/5/2010 accepted 4/10/2010 
first order using a batch technique and a zero order with a miscible displacement technique. On the basis of least square regression analysis, Dhillon and Dhillon (1990) observed that the parabolic diffusion equation could explain better the kinetics of non- exchangeable K release. Recently, Hundal and Pasricha (1993), however, observed two simultaneous first order equations indicating both a rapid and a slow reaction rate.

The objectives of the present investigation were (1) to determine the rate of $\mathrm{K}$ desorption between exchangeable and solution phases in soil samples previously examined for $\mathrm{K}$ adsorption characteristics. The magnitude and rate of $\mathrm{K}$ desorption were determined using a miscible displacement technique. (2) to determine apparent $\mathrm{K}$ desorption rate coefficients $\left(\mathrm{K}_{\mathrm{d}}\right)$ and reaction order.

\section{MATERIALS AND METHODS}

Seven soil samples belonging to agriculturally important soils were taken from agricultural regions in Sulaimani governorate in Kurdistan region, Iraq to study of kinetics of $\mathrm{K}$ desorption. The soil particle size distribution was determined by the pipette method (Gee and Bauder, 1986). Organic matter (OM) was determined by dichromate oxidation (Walkley and Black) procedure (Nelson and Sommers, 1986). $\mathrm{pH}$ was measured in a saturated paste using a combination electrode (Robbins and Wiegand, 1990); Electrical conductivity $\left(\mathrm{EC}_{\mathrm{e}}\right)$ was measured for the soil saturation extract with EC-meter, model ((WTW82362 Weilheim, Germany); soluble $\mathrm{CO}_{3}, \mathrm{HCO}_{3}, \mathrm{Cl}$ and $\mathrm{Ca}+\mathrm{Mg}$ by titration methods (Page et al., 1982); $\mathrm{Na}$ and $\mathrm{K}$ by flame photometer; Cation exchange capacity (CEC) was obtained by saturation with $1 M$ ammonium acetate $\left(\mathrm{NH}_{4} \mathrm{OAc}\right)$ at $\mathrm{pH} 8.1$ as an extraction solution (Polemio and Roades, 1977). Total calcium carbonate $\left(\mathrm{CaCO}_{3}\right)$ in the soil, expressed as the calcium carbonate equivalent (CCE) was determined by a rapid titration method (Rayment and Higginson, 1992). The active lime or active $\mathrm{CaCO}_{3}$ equivalent (ACCE), which is fine particle- size calcite, was determined by the $0.5 \mathrm{M} \mathrm{NH} 4-$ oxalate method (Drouineau, 1942). Physical and chemical characteristics of the soil samples are given in table $(1,2)$.

Table (1): some physical properties of investigated soils.

\begin{tabular}{|c|c|c|c|c|c|c|}
\hline \multirow{2}{*}{ Location } & \multirow{2}{*}{$\begin{array}{c}\text { Depth } \\
\mathrm{cm}\end{array}$} & \multirow{2}{*}{ Soil order } & \multicolumn{3}{|c|}{ PSD g kg-1 $^{-1} \begin{array}{c}\text { Texture } \\
\text { Class }\end{array}$} \\
\cline { 4 - 6 } & & Sand & Silt & Clay & \\
\hline Bazyan & $0-10$ & Entisols & 58.6 & 574.5 & 366.9 & SiCL \\
\hline Arbat & $0-15$ & Entisols & 62.9 & 543.9 & 393.2 & SiCL \\
\hline Bakrajow & $0-12$ & Vertisols & 69.8 & 464.4 & 465.8 & SiC \\
\hline Qlyasan & $0-12$ & Vertisols & 99.6 & 430.1 & 470.3 & SiC \\
\hline Kanypanka & $0-25$ & Mollisols & 33.9 & 508.0 & 458.1 & SiC \\
\hline Said Sadiq & $0-10$ & Mollisols & 174.5 & 377.0 & 448.5 & C \\
\hline Serwa & $0-18$ & Mollisols & 13.14 & 443.5 & 543.3 & SiC \\
\hline
\end{tabular}

Kinetics of Desorption Studies: The miscible displacement technique used for desorption studies as described by (Sparks and Rechcigl, 1982; Chaudhary 
and Prasad, 1999).A duplicate $1.00 \mathrm{gm}$ of soil samples previously examined for $\mathrm{K}$ adsorption characteristics in to $47 \mathrm{~mm}$ Nucleopore filter- column. The soil samples were leached with $0.01 M \mathrm{CaCl}_{2}$ The solution of $\mathrm{CaCl}_{2}$ was passed through the soil at flow velocities of $1 \mathrm{ml} \mathrm{min}^{-1}$. Ten- milliliter aliquots were collected until $\mathrm{K}$ was not detected in the leachate. Potassium in the leachate

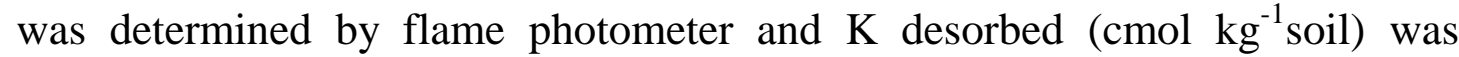
calculated.

Table (2): some chemical properties of investigated soils

\begin{tabular}{|c|c|c|c|c|c|c|c|c|}
\hline \multirow{2}{*}{\multicolumn{2}{|c|}{ Soil properties }} & \multicolumn{7}{|c|}{ Locations } \\
\hline & & Bazyan & Arbat & Bakrajow & Qlyasan & Kanypanka & Said Sadiq & Serwa \\
\hline \multicolumn{2}{|c|}{ pH } & 7.83 & 8.18 & 7.54 & 7.90 & 7.46 & 7.80 & 7.65 \\
\hline \multicolumn{2}{|c|}{$E C_{e}\left(d S m^{-1}\right)$} & 0.52 & 0.38 & 0.66 & 0.52 & 0.27 & 0.42 & 0.33 \\
\hline \multicolumn{2}{|c|}{$\begin{array}{c}\text { CEC } \\
\left(\mathrm{cmol}_{\mathrm{c}} \mathbf{~ k g}^{-1}\right)\end{array}$} & 46.18 & 51.56 & 48.94 & 50.25 & 55.33 & 50.74 & 50.84 \\
\hline \multicolumn{2}{|c|}{ O. M. $\left(\mathrm{g} \mathrm{kg}^{-1}\right)$} & 31.70 & 30.50 & 24.40 & 33.70 & 26.50 & 29.80 & 23.20 \\
\hline \multirow{2}{*}{$\begin{array}{c}\mathrm{CaCO}_{3} \\
\text { equ. } \\
\left(\mathrm{g} \mathrm{kg}^{-1}\right)\end{array}$} & Total & 197.70 & 33.80 & 325.50 & 389.40 & 225.50 & 81.60 & 150.00 \\
\hline & active & 70.00 & 20.00 & 110.00 & 150.00 & 100.00 & 10.00 & 65.00 \\
\hline \multirow{7}{*}{ 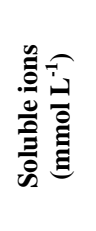 } & $\mathrm{Ca}^{2+}$ & 2.11 & 1.79 & 2.62 & 2.38 & 1.16 & 1.67 & 1.47 \\
\hline & $\mathbf{M g}^{2+}$ & 0.91 & 0.49 & 0.70 & 0.48 & 0.34 & 0.58 & 0.32 \\
\hline & $\mathrm{Na}^{+}$ & 0.47 & 0.41 & 0.50 & 0.41 & 0.42 & 0.43 & 0.44 \\
\hline & $\mathbf{K}^{+}$ & 0.11 & 0.01 & 0.11 & 0.11 & 0.08 & 0.13 & 0.01 \\
\hline & $\mathrm{HCO}_{3}{ }^{-1}$ & 5.08 & 4.39 & 4.16 & 3.76 & 2.75 & 3.63 & 3.34 \\
\hline & $\mathrm{Cl}^{-1}$ & 0.78 & 0.30 & 1.10 & 0.86 & 0.42 & 0.88 & 0.66 \\
\hline & $\mathrm{SO}_{4}^{2-}$ & 0.87 & 0.79 & 0.87 & 0.88 & 0.93 & 0.87 & 0.85 \\
\hline
\end{tabular}

Potassium desorption ( $\mathrm{cmol} \mathrm{kg}^{-1}$ soil) with time was fitted employing different kinetic equations, namely zero order, first order, Elovich, parabolic diffusion, and power function equations:

Zero order equation: $\quad \mathrm{C}_{\mathrm{t}}=\mathrm{C}_{\mathrm{o}}-\mathrm{Kt}$

First order equation: $\quad \ln \left(\mathrm{C}_{\mathrm{t}} / \mathrm{C}_{\mathrm{o}}\right)=\mathrm{K}_{\mathrm{d}} \mathrm{t}$

Where:

$$
\begin{array}{ll} 
& \mathrm{K}_{\mathrm{d}}=\text { desorption rate coefficient of potassium } \\
& \mathrm{C}_{\mathrm{t}}=\text { amount of desorbed potassium at time } t\left(\mathrm{cmol} \mathrm{kg}^{-1} \text { soil }\right) \\
& \mathrm{C}_{\mathrm{o}}=\text { amount of desorbed potassium at equilibrium }\left(\mathrm{cmol} \mathrm{kg}^{-1}\right. \\
\text { soil) } & \\
\mathrm{t}=\text { time in hours }
\end{array}
$$

The value of desorption rate coefficient $\left(\mathrm{K}_{\mathrm{d}}\right)$ were calculated from the slope of linear relationship between $\log \left(\mathrm{C}_{\mathrm{t}} / \mathrm{C}_{\mathrm{o}}\right)$ vs. $t$.

$$
\text { Elovich equation : } \quad \mathrm{C}_{\mathrm{t}}=1 / \mathrm{K} \ln \left(\mathrm{C}_{\mathrm{o}} \mathrm{K}\right)-1 / \mathrm{K} \operatorname{lnt}
$$

Plotting $\mathbf{C}_{\mathbf{t}}$ versus the term of the duration of the extraction (lnt) the Elovich equation will be a straight line with the slop $(1 / \mathrm{K})$ and logarithmic intercept $\left(1 / \mathrm{K} \ln \left(\mathrm{C}_{\mathrm{o}} \mathrm{K}\right)\right.$, the slop of straight line was expressed for the rate coefficient of desorption of $\mathrm{K}$.
Parabolic equation:

$$
\mathrm{C}_{\mathrm{t}}=\mathrm{C}_{\mathrm{o}}+\mathrm{K}_{\mathrm{d}} \mathrm{t}^{1 / 2}
$$

Where, ' $\mathrm{C}_{\mathrm{t}}$ ' is the amount of $\mathrm{K}$ desorbed at time ' $\mathrm{t}$ ', ' $\mathrm{C}_{\mathrm{o}}$ ' is the amount of desorbed $\mathrm{K}$ at equilibrium and ' $\mathrm{K}_{\mathrm{d}}$ ' is the overall diffusion coefficient and ' $\mathrm{t}$ ' is the time in hours. 
Power function equation: $\quad \ln \mathrm{C}_{\mathrm{t}}=\ln \mathrm{C}_{\mathrm{o}}+\mathrm{k} \ln \mathrm{t}$

Where:

$$
\mathbf{C}_{\mathbf{t}}=\text { the amount of } \mathrm{K} \text { desorbed at time } \mathrm{t} \text {. }
$$

The equations used to describe the kinetics of $\mathrm{K}$ desorption were evaluated by comparing the linear coefficient of determination $\left(\boldsymbol{R}^{2}\right)$ and the standard error $(\boldsymbol{S E})$ of the estimate. This $\boldsymbol{S E}$ was calculated according to the equation:

$$
\mathrm{SE}=\left[\Sigma\left(\mathrm{C}_{\mathrm{t}}-\mathrm{C}_{\mathrm{t}}^{*}\right)^{2} / \mathrm{n}-2\right]^{1 / 2}
$$

Where ' $\boldsymbol{C}_{\boldsymbol{t}}$ ' and ' $\boldsymbol{C}_{\boldsymbol{t}}^{*}$ ' represent the amount of metal measured and calculated at time ' $\boldsymbol{t}$ ' respectively, and ' $\boldsymbol{n}$ ' is the number of measurement points for each equation which were determined by least squares regression analysis (Martin and Sparks, 1983; Havlin et al., 1985).

\section{RESULTS AND DISCUSSION}

The results of $\mathrm{K}$ desorption by miscible displacement technique are describe according to mathematical kinetic linear equations to choice the best equation depending on highest value of coefficient of determination $\left(\mathrm{R}^{2}\right)$ and the lowest value of standard error of estimate (SE) (Sparks, 1992). Table (3) show all equations describe the reaction rate of $\mathrm{K}$ desorption in the studied soils as evidenced by the over all highest value of $\left(\mathrm{R}^{2}\right)$ and lowest (SE) however potassium desorption in the studied soils conformed to Elovich and parabolic diffusion kinetic equations.

This result is agreed with finding by (Sivasubramanim and Talibudeen, 1972; Dhillon and Dhillon, 1990).

Table (3): Show the value of $\mathrm{R}^{2}$ and SE for $\mathrm{K}$ desorption from the studied soils

\begin{tabular}{|c|c|c|c|c|c|c|c|c|c|c|}
\hline \multirow{2}{*}{ Location } & \multicolumn{2}{|c|}{ Zero order } & \multicolumn{2}{c|}{ First order } & \multicolumn{2}{c|}{ Elovich } & \multicolumn{2}{c|}{ Parabolic } & \multicolumn{2}{c|}{ Power function } \\
\cline { 2 - 11 } & SE & $\mathbf{R}^{2}$ & SE & $\mathbf{R}^{2}$ & SE & $\mathbf{R}^{2}$ & SE & $\mathbf{R}^{2}$ & SE & $\mathbf{R}^{2}$ \\
\hline Bazyan & $\mathbf{0 . 0 5 2}$ & $\mathbf{0 . 9 1 2}$ & $\mathbf{0 . 0 8 9}$ & $\mathbf{0 . 7 9 7}$ & $\mathbf{0 . 0 0 6}$ & $\mathbf{0 . 9 9 5}$ & $\mathbf{0 . 0 1 3}$ & $\mathbf{0 . 9 7 6}$ & $\mathbf{0 . 0 7 1}$ & $\mathbf{0 . 9 7 6}$ \\
\hline Arbat & $\mathbf{0 . 0 5 1}$ & $\mathbf{0 . 9 1 4}$ & $\mathbf{0 . 0 8 8}$ & $\mathbf{0 . 7 9 3}$ & $\mathbf{0 . 0 0 4}$ & $\mathbf{0 . 9 9 8}$ & $\mathbf{0 . 0 1 3}$ & $\mathbf{0 . 9 7 7}$ & $\mathbf{0 . 0 7 2}$ & $\mathbf{0 . 9 7 4}$ \\
\hline Bakrajow & $\mathbf{0 . 0 5 6}$ & $\mathbf{0 . 8 9 3}$ & $\mathbf{0 . 0 8 7}$ & $\mathbf{0 . 7 7 8}$ & $\mathbf{0 . 0 0 4}$ & $\mathbf{0 . 9 9 7}$ & $\mathbf{0 . 0 1 2}$ & $\mathbf{0 . 9 6 6}$ & $\mathbf{0 . 0 7 0}$ & $\mathbf{0 . 9 6 8}$ \\
\hline Qlyasan & $\mathbf{0 . 0 7 9}$ & $\mathbf{0 . 7 6 0}$ & $\mathbf{0 . 0 8 6}$ & $\mathbf{0 . 6 6 2}$ & $\mathbf{0 . 0 0 9}$ & $\mathbf{0 . 9 6 0}$ & $\mathbf{0 . 0 1 7}$ & $\mathbf{0 . 8 7 2}$ & $\mathbf{0 . 1 0 5}$ & $\mathbf{0 . 9 0 6}$ \\
\hline Kaneypanka & $\mathbf{0 . 0 2 5}$ & $\mathbf{0 . 9 6 6}$ & $\mathbf{0 . 0 9 9}$ & $\mathbf{0 . 8 4 2}$ & $\mathbf{0 . 0 1 7}$ & $\mathbf{0 . 9 7 9}$ & $\mathbf{0 . 0 2 1}$ & $\mathbf{0 . 9 9 7}$ & $\mathbf{0 . 0 5 6}$ & $\mathbf{0 . 9 9 1}$ \\
\hline Said Sadiq & $\mathbf{0 . 0 5 3}$ & $\mathbf{0 . 9 1 4}$ & $\mathbf{0 . 0 7 1}$ & $\mathbf{0 . 8 0 8}$ & $\mathbf{0 . 0 0 2}$ & $\mathbf{0 . 9 9 9}$ & $\mathbf{0 . 0 1 0}$ & $\mathbf{0 . 9 9 8}$ & $\mathbf{0 . 0 5 4}$ & $\mathbf{0 . 9 7 9}$ \\
\hline Serwan & $\mathbf{0 . 0 4 2}$ & $\mathbf{0 . 9 5 4}$ & $\mathbf{0 . 0 6 9}$ & $\mathbf{0 . 8 6 0}$ & $\mathbf{0 . 0 0 9}$ & $\mathbf{0 . 9 8 8}$ & $\mathbf{0 . 0 0 6}$ & $\mathbf{0 . 9 9 5}$ & $\mathbf{0 . 0 3 1}$ & $\mathbf{0 . 9 9 5}$ \\
\hline mean & $\mathbf{0 . 0 5 1}$ & $\mathbf{0 . 9 0 2}$ & $\mathbf{0 . 0 8 4}$ & $\mathbf{0 . 7 9 1}$ & $\mathbf{0 . 0 0 7}$ & $\mathbf{0 . 9 8 8}$ & $\mathbf{0 . 0 1 3}$ & $\mathbf{0 . 9 6 6}$ & $\mathbf{0 . 0 6 6}$ & $\mathbf{0 . 9 7 0}$ \\
\hline
\end{tabular}

The rate coefficient of $\mathrm{K}$ desorption $\left(\mathrm{K}_{\mathrm{d}}\right)$ by using miscible displacement to Elovich equation ranged between 0.0604 and $0.1441 \mathrm{cmol} \mathrm{kg}^{-1} \mathrm{~min}^{-1}$. In the whole soil, the highest rate constant was for Kanypanka location soil (Mollisols), and the lowest for Qlyasan location soil (Vertisols) as shown in table (4). While the rate coefficient $\mathrm{K}$ desorption $\left(\mathrm{K}_{\mathrm{d}}\right)$ according to parabolic diffusion equation ranged between 0.0188 and $0.0476 \mathrm{cmol} \mathrm{kg}^{-1} \mathrm{~min}^{-1 / 2}$ the highest rate constant also for Kanypanka location soil (Mollisols) and the lowest value for Qlyasan location soil (Vertisols). This apparent discrepancy may be attributed to the difference in type and content of minerals in clay fractions.

The external planar surface sites and the edge sites desorbed $\mathrm{K}$ readily while the desorption of $\mathrm{K}$ from interlayer sites involved a slow rate of diffusion 
(Sawhney, 1966). The diffusion was the predominant mechanism of $\mathrm{K}$ desorption in these soils as illustrated in figures (1 and 2) by the linear relation between the cumulative desorbed $\mathrm{K} \mathrm{cmol} \mathrm{kg}^{-1}$ and 1 nt for Elovich equation and between the cumulative desorbed $\mathrm{K} \mathrm{cmol} \mathrm{kg}{ }^{-1}$ and time ${ }^{1 / 2}$ for parabolic diffusion equation.

Table (4): Apparent desorption rate coefficients $\left(\mathrm{K}_{\mathrm{d}}\right)$ calculated at $1.0 \mathrm{ml} \mathrm{min}{ }^{-1}$ flow velocity, of studied soils

\begin{tabular}{|c|c|c|c|c|c|}
\hline Location & $\begin{array}{c}\text { Zero order } \\
\mathrm{Cmol} \mathrm{kg}^{-1} \\
\mathrm{~min}^{-1}\end{array}$ & $\begin{array}{c}\text { First order } \\
\mathrm{min}^{-1}\end{array}$ & $\begin{array}{c}\text { Elovich } \\
\mathrm{cmol} \mathrm{kg}^{-1} \\
\mathrm{~min}^{-1}\end{array}$ & $\begin{array}{c}\text { Parabolic } \\
\mathrm{cmol} \mathrm{kg}^{-1} \\
\mathrm{~min}^{-1 / 2}\end{array}$ & $\begin{array}{c}\text { Power function } \\
\mathrm{cmol} \mathrm{kg}^{-1} \mathrm{~min}^{-1}\end{array}$ \\
\hline Bazyan & -0.0052 & 0.0055 & 0.1102 & 0.0357 & 0.5778 \\
\hline Arbat & -0.0051 & 0.0054 & 0.1075 & 0.0348 & 0.5663 \\
\hline Bakrajow & -0.0051 & 0.0051 & 0.0816 & 0.0263 & 0.5401 \\
\hline Qlyasan & -0.0044 & 0.0038 & 0.0604 & 0.0188 & 0.4198 \\
\hline Kaneypanka & -0.0042 & 0.0072 & 0.1441 & 0.0476 & 0.7401 \\
\hline Said Sadiq & -0.0054 & 0.0045 & 0.088 & 0.0285 & 0.4744 \\
\hline Serwan & -0.006 & 0.0053 & 0.1072 & 0.0352 & 0.5405 \\
\hline mean & -0.0050 & 0.0052 & 0.0999 & 0.0324 & 0.8418 \\
\hline
\end{tabular}

The slops of the relation of cumulative desorbed $\mathrm{K}$ and lnt for Elovich equation and time $^{-1 / 2}$ for parabolic diffusion equation are different for investigated soils. Similar type of relationship between per cent K desorbed and time $^{1 / 2}$ was reported by (Sparks et al., 1980; Choudhary and Prasad, 1997) in soils of varying clay content. 

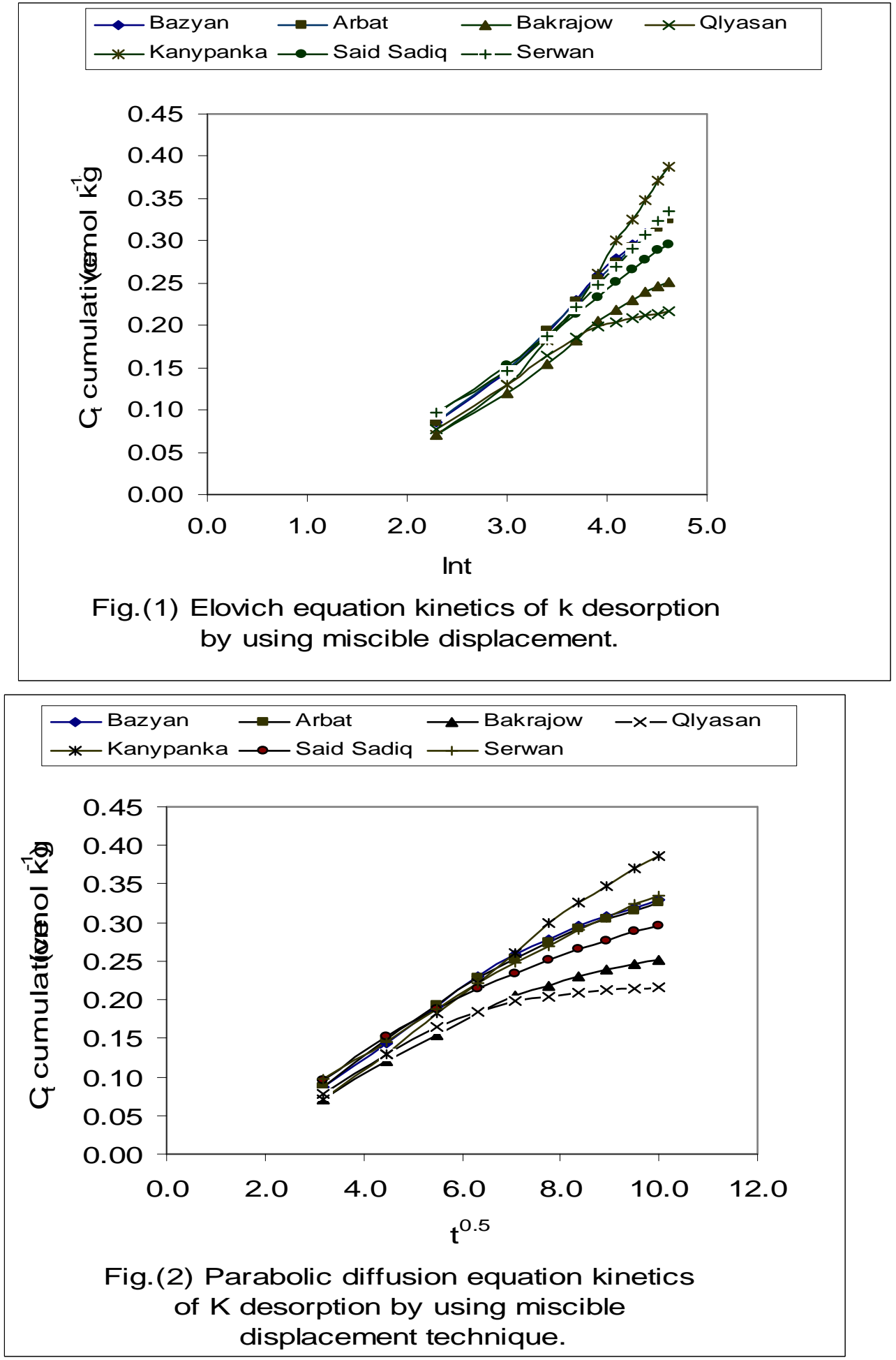

حركيات تحرر البوتاسيوم لترب إنتيسول فيرتيسول و موليسول في محافظة السليمانية

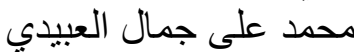

جامعة الموصل / كلية الزراعة الزيل

قسم علوم التربة و المية الزرياه
غفور احمد مام رسول الزيل جامعة السليمانية / كلية الزراعة الهية

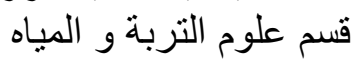

\section{الخلاصة}




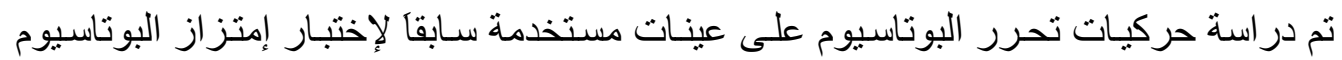

لطبقات سطحية لسبع ترب محافظة السليمانية في كوردستان العر اق بإستخدام تقنيـة الإز احسة الإمتز اجية التية الهادئة .

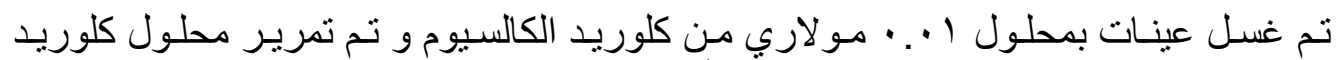

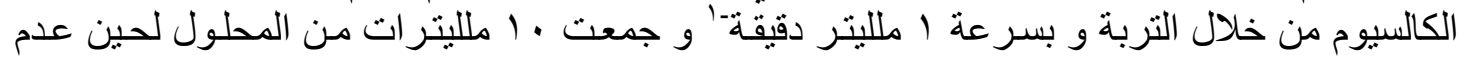

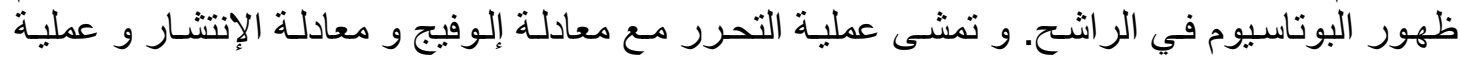

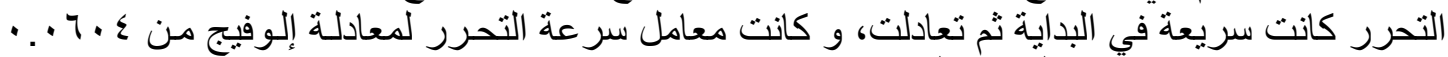

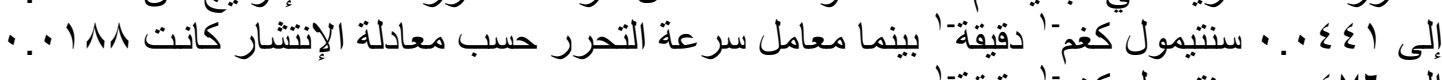

\section{REFERENCES}

Choudhary, K. and B. Parasad(1997). Kinetics of potassium desorption from inceptisols and entisols. Journal. Indian. Soc. Soil. Sci.45:460-464.

Chaudhary, K. and B. Prasad (1999). Thermodynamics of potassium exchange reaction in entisol and vertisol using a kinetic approach by miscible displacement technique. J. of the Indian Soc. Soil Sci. 2. 221-229.

Dhillon, S. K. and K. S. Dhillon (1990). Kinetics of release of nonexchangeable potassium by cation-saturated resins from red Alfisols, black vertisols and alluvial (Inceptisols) soils of India. Geoderma 47: 283300 .

Drouineau, G. (1942). Dosage rapide du calcaire actif du soil: nouvelles donnees surla separation et al nature des fractions calcaires. Ann Agron., 12: 441-450.

Gee, G. W. and J. W. Bauder (1986). Particle-size analysis. P 383-412.In A. Klute (ed.) Methods of Soil Analysis: Physical and Mineralogy Methods, Part I. Second ed. ASA and SSSA, Madison, WI.

Havlin, J. L., D. G. Westfall, and S.R. Olsen (1985). Mathematical models for potassium release kinetics in calcareous soils. Soil Sci. Soc. Am. J. 49: 371-376.

Hundal, L. S. and N. S. Pasricha (1993). Non-exchangeable potassium kinetics in illitic soil profiles. Soil Sci. 156:34-41.

Jardine, P. M., and D. L. Sparks (1984). Potassium-calcium exchange in a multireactive soil system: I. Kinetics. Soil Sci. Soc. of Am. J. 48: 39-45.

Martin, H. W. and D. L. Sparks(1983). Kinetics of nonexchangeable potassium release from two coastal plain soils. Soil Sci. Soc. Am. J. 47:883-887.

Mortland, M. M. (1958). Kinetics of potassium release from biotite. Soil Sci. Soc. of Am. Proc. 22: 503-508.

Nelson, D. W. and L.E. Sommer(1986).Total carbon, organic carbon and organic matter. In: Page, Methods of Soil Analysis A.L., R.H. Millerand D.R. Kreney, (eds).pp539-579Part.2Agron. 9 SSSA. Madison, W.I. USA.

Page, A. L., R. H. Miller and D. R. Kenney, (Ed.) (1982). Methods of Soil Analysis. Part 2. Am. Soc. Agric. Pub. Madison, W.I. U S A.

Polemio, M. and J. D. Roades (1977). Determining cation exchange capacity. A new procedure for calcareous and gypsiferous soils. Soil Sci. Soc. Am. J.

Rayment, G. E. and F. R. Higginson (1992). Australian Laboratory Handbook of Soil and water Chemical Methods. Inkata Press. 
Robbins, C. W., and C. L. Wiegand (1990). Field and laboratory measurements. In: Agricultural Salinity Assessment and Management. K.K. Tanji (ed.) Am. Soc. Civil Eng., New York, pp 201-219.

Sawhney, B. L. (1966). Kinetics of cesium sorption by clay minerals. Soil Sci. Soc. Am. Proc. 30: 565-569.

Sivasubramaniam, S., and O. Talibudeen (1972). Potassium aluminum exchange in acid soil. I. Kinetics. J. Soil. Sci. 23:163-176.

Sparks, D. L., L. W. Zelanzy, and D. C. Martens (1980). Kinetics of potassium desorption in soil using miscible displacement. Soil Sci. Soc. Am. J. 44: 1205-1208.

Sparks, D. L. and J. E. Rechcigl, (1982).Comparison of batch and miscible displacement techniques to describe potassium adsorption kinetics in Delaware soils. Soil Sci. Soc. Am. J. 46:875-877.

Sparks, D. L., 1992. Kinetics of Soil Chemical Processes. Academic Press, Inc., (England).

Talibudeen, O., J. D. Beasley, P. Leone, and N. Rajendran (1978). Assessment of soil potassium reserves available to plant roots. J. Soil Sci. 29:207-218. 